\title{
MAJORITY/PLURALITY SYSTEMS: THE CHOICE OF LEAST DEVELOPED COUNTRIES?
}

\author{
D. Pastarmadzhieva* \\ Department of Political Sciences and National Security, University of Plovdiv Paisii Hilendarski \\ Plovdiv, Bulgaria
}

\begin{abstract}
The electoral system of a country is related to the political, economic and social areas of life. Their functioning directly or indirectly depends on it and the different types and subtypes of electoral systems produce different effects.

The purpose of the current study is to identify if there is a relation between the statute of the least developed countries and their electoral system. The object of the study are countries, defined as least developed in 2018 by the United Nations. The focus is the type of electoral system for the legislative body (or its lower chamber in case of bicameralism) of these countries, their regime type, overall score and the score for electoral process and pluralism according to EIU Democracy Index 2018.

For the purposes of the analysis statistical methods (frequencies, hypothesis test and chi-square test) and comparative approach are used. The results show that there is statistically significant relationship between the statute of least developed countries and their electoral system on one hand and their regime type on other. There is also a statistically significant difference in the scores of least developed countries compared to all others regarding the evaluation of democracy and the electoral process and pluralism.
\end{abstract}

Keywords: democracy, elections, majority/plurality systems, economic development

\section{INTRODUCTION}

The countries conduct different types of elections - parliamentary, presidential, local, etc. Each of them is significant for the functioning of democracy but those for the formation of the legislature are the basis of the democratic idea. They are means, by which various social groups may achieve a representation in the governing institutions and are a mechanism by which the citizens can replace one political party with another, when are dissatisfied.

There is an empirical evidence that there isn't a perfect way for ensuring representation or in other words there isn't a perfect electoral system. Nevertheless, there are three basic choices between which a country must select, namely plurality/majority system, proportional

\footnotetext{
*Correspondence to: Daniela Pastarmadzhieva, Department of Political Sciences and National Security, University of Plovdiv Paisii Hilendarski, Tzar Asen str. 24, Plovdiv 4000, Bulgaria, +359884727096,

daniela.pastarmadjieva@gmail.com
}

representation and mixed system. The selection of electoral system is not isolated from other structures of the political system. Furthermore, the electoral system is related to the economic development in various ways.

The purpose of the current study is to identify if there is a connection between the statute of the least developed countries and their electoral system. The object of the study are countries, defined as least developed in 2018 by the United Nations. The focus is the type of electoral system for the legislative body (or its lower chamber in case of bicameralism) of these countries, their regime type, overall score and the score for electoral process and pluralism according to EIU Democracy Index 2018. For the purposes of the analysis statistical methods (frequencies, hypothesis test and chi-square test) and comparative approach are used.

WHY ELECTORAL SYSTEM MATTER?

The contemporary democratic political systems are based on representation, which means that 
a "small number of individuals to represent a much larger number of citizens". The electoral system is the set of rules and formulas, which transform the "citizens' votes into legislature seats" and this transformation can be made in a number of ways and can produced different results. (1)

The electoral system is related to various aspects of the functioning of the country, namely party system, political stability, representation of minorities, economic growth and policies, etc.

Traditionally, the plurality voting produces two-party system (known as Duverger's law) and the proportional representation and tworound system leads to multi-partism (known as Duverger's hypothesis) (2). Mixed systems can produce different results, depending on the way the in which plurality/majority is combined with the proportional representation. (3)

The effect, which the electoral system has on the party system is related to the political stability. Usually, the majority/plurality systems produce stable single-party governments, which is supposed to facilitate the decision-making process (4). Nevertheless, we should be aware that the majority created by such system can be "a natural or a manufactured" (5). This means that the political party, which gets the most of the seats is not necessarily the most supported by the society. Furthermore, the majority/plurality system is not suitable for divided societies as it can deepen the conflicts by making some social groups feeling under-represented (6).

On the contrary, proportional representation, depending on the formula for the allocation of seats, very often leads to coalition governments, which face more difficulties in decision-making (4). However, the correlation between the type of electoral system and the stability of governments is indirect as the latter depends on the party system, which is directly affected by the electoral system type. (7)

The type of electoral system also affects the representation of various social group. A very popular topic is the representation of women in the legislative bodies according to the type of electoral system. There is a special report of the Venice Commission on the impact of electoral systems on women's representation in politics. According to the latter there is a higher share of women in the legislatures of 108 countries with proportional representation systems in comparison to the countries with majority/plurality systems. It appears that the result for the states, which implement mixed systems, is somewhere between the majority/plurality and proportional representation systems. (8)

It also affects the economic growth and policies. In his study of the economic origins of dictatorship and democracy Acemoglu and Robinson mention that there is an empirical evidence that proportional representation systems produce greater income redistribution than majoritarian ones (9). Electoral systems is also important for the economic development, because indirectly the voters choose the economic policy, which is part of the party's platform (9). The empirical data, used by Pippa Norris shows that the countries with proportional representation "have slightly higher levels of per capita GDP" and "are rated as slightly more democratic" compared to the countries, using majority/plurality systems (5).

Similarly to the research, mentioned above, the current study also aims at identifying dependency between the type of electoral system and the development of the countries.

\section{MATERIALS AND METHODS}

As already mentioned, the object of this study are the least developed countries in 2018 as defined by the UN. These are "low-income countries suffering from structural impediments to sustainable development". The Committee for Development Policy uses three indicators to identify the LDCs, namely: gross national income (GNI) per capita; human assets index (HAI) and economic vulnerability index (EVI) (10).

In 2018 in the UN list of least developed countries are 47 states. Four of them are not included in the study as they don't have direct elections for the legislative body or there is no confirmed information about their electoral system. These are Eritrea, Somalia, South Sudan and Vanuatu.

For the purposes of the study a data file is created in IBM SPSS Statistics 23. It consists of the following variables:

1) Country - there are 165 countries included in the study;

2) Type of electoral system majority/plurality, proportional representation and mixed systems. For the type of electoral system of each country are used various 
sources - official institutional websites, ACE The Electoral Knowledge Network(11), InterParliamentary Union (12), Institute for Democracy and Electoral Assistance (13) and The International Foundation for Electoral Systems (14);

3) Least developed country - "yes" if the country is defined as "least developed" or "no" if it is not;

Table 1. Least developed countries in 2018

\begin{tabular}{|c|c|c|c|c|c|}
\hline & & & & & \\
\hline Afghanistan & $\begin{array}{l}\text { Central African } \\
\text { Republic }\end{array}$ & Guinea & Malawi & $\begin{array}{l}\text { Sao Tome } \\
\text { and Principe }\end{array}$ & Togo \\
\hline Angola & Chad & Guinea-Bissau & Mali & Senegal & Tuvalu \\
\hline Bangladesh & Comoros & Haiti & Mauritania & $\begin{array}{l}\text { Sierra } \\
\text { Leone }\end{array}$ & Uganda \\
\hline Benin & $\begin{array}{l}\text { Democratic } \\
\text { Republic of the } \\
\text { Congo }\end{array}$ & Kiribati & Mozambique & $\begin{array}{l}\text { Solomon } \\
\text { Islands }\end{array}$ & $\begin{array}{l}\text { United } \\
\text { Republic of } \\
\text { Tanzania }\end{array}$ \\
\hline Bhutan & Djibouti & $\begin{array}{l}\text { Lao People's } \\
\text { Democratic Republic }\end{array}$ & Myanmar & Somalia & Vanuatu \\
\hline Burkina Faso & Eritrea & Lesotho & Nepal & South Sudan & Yemen \\
\hline 3urundi & Ethiopia & Liberia & Niger & Sudan & Zambia \\
\hline Cambodia & Gambia & Madagascar & Rwanda & Timor-Leste & Togo \\
\hline
\end{tabular}

4) Type of regime according to EIU Democracy Index 2018 (15) - full democracy, flawed democracy, hybrid regime and authoritarian regime;

5) Overall score for democratic performance according to EIU Democracy Index 2018 (15); 6) Score for electoral process and pluralism according to EIU Democracy Index 2018 (15).

Source: (16)

Thus, in the current study we use three variables, which are nominal data, namely, type of electoral system, categorization of countries as least developed or not and the type of regimes as defined by the EIU Democracy Index. We also have two on ordinal scale - the overall score for the democracy and the score for electoral process and pluralism.

In order to present the results, frequencies were made, also chi-square and hypothesis test were performed.

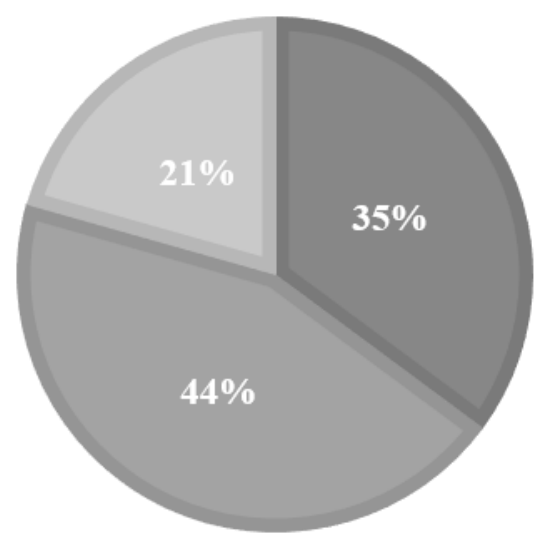

\section{RESULTS AND DISCUSSION}

Among the studied countries there are 58 with majority/plurality system (35\%), 73 with proportional representation $(44 \%)$ and the mixed are 34 , which is $21 \%$ of the studied countries. Thus, the data shows that the most common electoral system is proportional representation. (Figure 1)

Figure 1. Share of electoral system types among the studied countries

About $1 / 4$ of the studied countries $(26 \%)$ are in the list of the LDCs for 2018 and their number is 43 out of 47 in total. Thus, we can make a comparison with the results for the other countries, which are not in the list. (Figure 2) 


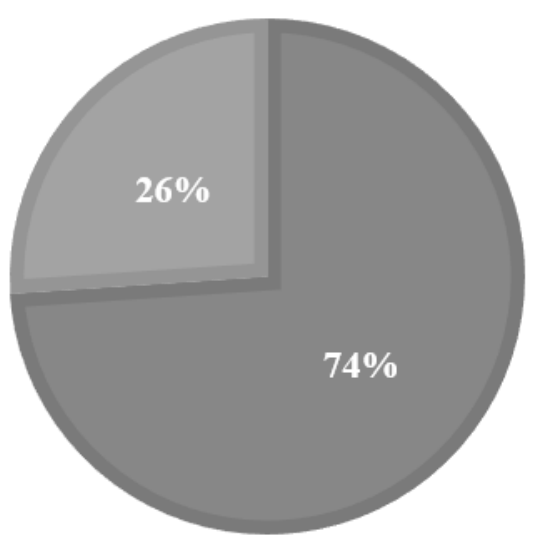

Not in the group of LDCs

- Least Developed Countries

Figure 2. Share of the least developed countries

Figure 3 presents the share of each regime type as they are defined in the EIU Democracy Index. Of all the studied 165, there is data from the EIU Democracy Index for 155 of them. Flawed democracies has the highest share -

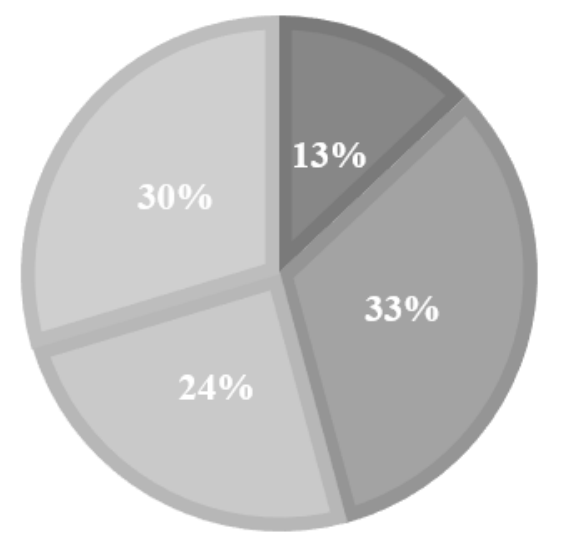

$33 \%$ and their number is 51 . A little bit lower is the number of authoritarian regimes, namely 46 , which represents $30 \%$. There are 38 hybrid regimes $(24 \%)$ and the full democracies are only out of 155 , which is as low as $13 \%$.

Figure 3. Distribution of regime types among the studied countries

Almost half of the least developed countries use majority/plurality system (49\%). Proportional representation and mixed system have equal share among these countries (Figure 4). This leads to the conclusion that

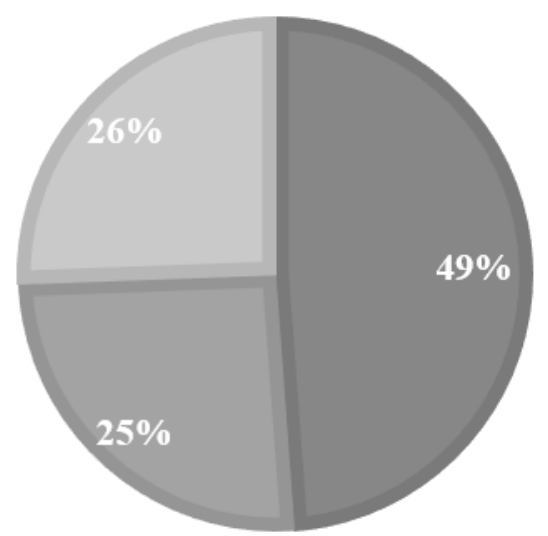

indeed the majority/plurality system is the most preferred among the LDCs. However, we also made a statistical hypothesis test in order to identify a connection.

Figure 4. Share of electoral system types among the least developed countries 
Another dependency was also identified. The least developed countries are characterized with authoritarian regimes. Such conclusion is

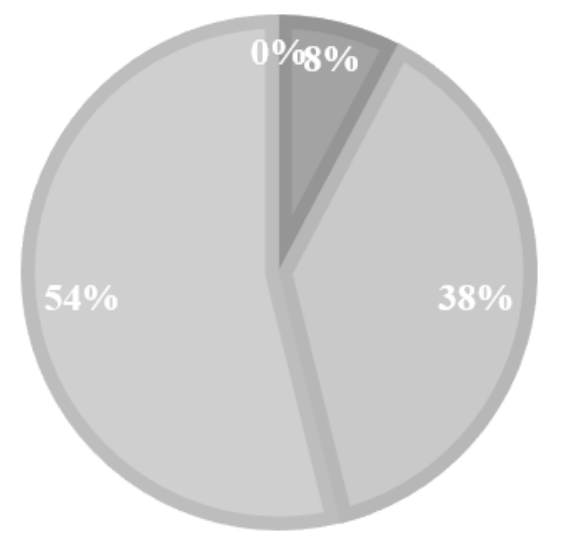

PASTARMADZHIEVA D. based on the crosstabs, which show that $54 \%$ of the LDCs have such regime and none of them are full democracies (Figure 5).

Figure 5. Distribution of regime types among the least developed countries

\section{Chi-square test}

In order to identify if there is a relation between the statute "least developed" countries and electoral system on one hand, and the statute "least developed" countries and regime type on the other, chi square test was used. The three requirements for the implication of the method were covered for both studied relations - the studied cases are over 50, there no expected counts under 1 or 5 .

Least Developed Countries*Type of Electoral System

Table 2. Chi-square tests for the relation Least Developed Countries*Type of Electoral System

Chi-Square Tests

\begin{tabular}{lrrr}
\hline & Value & df & \multicolumn{2}{c}{$\begin{array}{c}\text { Asymptotic } \\
\text { Significance (2-sided) }\end{array}$} \\
\hline Pearson Chi-Square & $8.375^{\mathrm{a}}$ & 2 & .015 \\
Likelihood Ratio & 8.689 & 2 & .013 \\
Linear-by-Linear Association & .818 & 1 & .366 \\
N of Valid Cases & 165 & & \\
\hline
\end{tabular}

a. 0 cells $(.0 \%)$ have expected count less than 5 . The minimum expected count is 8.86 .

For the connection Least developed countries*Type of electoral system the value in column "Asymptotic Significance (2-sided)" for Pearson Chi-Square is 0.015 , which is lower than $\alpha=0.05$. Thus, we accept the alternative hypothesis, which in our case is that there is statistically significant relationship between the statute of least developed countries and their electoral system. Furthermore, the value Cramér's $\mathrm{V}$ shows the strength of the association between these two variables.

Table 3. Value of Cramer's V for the association Least Developed Countries*Type of Electoral System Symmetric Measures

\begin{tabular}{llrr}
\hline & & Value & Approximate Significance \\
\hline Nominal by Nominal & Phi & .225 & .015 \\
& Cramer's V & .225 & .015 \\
N of Valid Cases & & 165 & \\
\hline
\end{tabular}

Its values is 0.225 , which is between 0.1 and 0.3 . This means that there is statistically significant relationship between the statute of least developed countries and their electoral system and this association is weak.

Least Developed Countries*Regime Type 
Table 4. Chi-square tests for the relation Least Developed Countries* Regime Type

Chi-Square Tests

\begin{tabular}{lccr}
\hline & Value & df & \multicolumn{2}{c}{$\begin{array}{c}\text { Asymptotic } \\
\text { Significance (2-sided) }\end{array}$} \\
\hline Pearson Chi-Square & $31.181^{\mathrm{a}}$ & 3 & .000 \\
Likelihood Ratio & 37.648 & 3 & .000 \\
Linear-by-Linear Association & 27.673 & 1 & .000 \\
N of Valid Cases & 155 & & \\
\hline 0 cells $(.0 \%)$ have expected count less than 5. The minimum expected count is 5.03. & &
\end{tabular}

a. 0 cells $(.0 \%)$ have expected count less than 5 . The minimum expected count is 5.03 .

For the connection Least developed countries*Regime type (EIU Democracy Index) the value in column "Asymptotic Significance (2-sided)" for Pearson Chi-Square is 0.000 , which is lower than $\alpha=0.05$. Thus, we accept the alternative hypothesis, which in our case is that there is statistically significant relationship between the statute of least developed countries and their regime type. Here, we also look at the value of Cramér's V to see the strength of the association between these two variables.

Table 5. Value of Cramer's V for the association Least Developed Countries* Regime Type

\begin{tabular}{llrr}
\multicolumn{3}{c}{ Symmetric Measures } \\
\hline & Value & Approximate Significance \\
\hline Nominal by Nominal & Phi & .449 & .000 \\
& Cramer's V & .449 & .000 \\
N of Valid Cases & & 155 & \\
\hline
\end{tabular}

Its values is 0.449 , which is between 0.3 and 0.7. This means that there is statistically significant relationship between the statute of least developed countries and their electoral system and this association is average.

\section{Hypothesis test}

The purpose of the hypothesis test is to see if there is statistically significant difference between the overall score of the EIU Democracy Index for the group of least developed countries and all the other countries, and between the score for electoral process and pluralism for the group of least developed countries and the others.

Thus, the null hypothesis is that there is not a statistically significant difference and the alternative hypothesis is that there is a statistically significant difference. A nonparametric test was used.

Table 6. Statistical differences in the scores of LDCs and the other countries for the overall performance of the democracy and for the electoral process and pluralism.

\section{Test Statistics ${ }^{\mathrm{a}}$}

\begin{tabular}{lrr}
\hline & $\begin{array}{c}\text { EIU Democracy Index } \\
\text { (Overall Score) }\end{array}$ & $\begin{array}{c}\text { EIU Democracy Index } \\
\text { (Electoral Process and } \\
\text { Pluralism) }\end{array}$ \\
\hline Mann-Whitney U & 1004.000 & 1126.000 \\
Wilcoxon W & 1784.000 & 1906.000 \\
Z & -5.187 & -4.702 \\
Asymp. Sig. (2-tailed) & .000 & .000 \\
\hline a. Grouping Variable: Least developed country & &
\end{tabular}

The value of Asymp. Sig. (2-tailed) for both of the groups is 0.000 and it is lower than $\alpha=$ 0.05. Thus, we accept the alternative hypothesis, namely there is statistically significant difference between the overall score of the EIU Democracy Index for the group of least developed countries and all the other countries. The same is valid for the statistically significant difference between the score for electoral process and pluralism for the group of least developed countries and the others. 
PASTARMADZHIEVA D.

Table 7. Mean scores of LDCs and the other countries for the overall performance of the democracy and for the electoral process and pluralism.

\begin{tabular}{llrr}
\multicolumn{2}{c}{ Report } \\
\hline \multicolumn{2}{l}{ Least developed country } & $\begin{array}{c}\text { EIU Democracy Index } \\
\text { (Overall Score) }\end{array}$ & $\begin{array}{c}\text { EIU Democracy Index } \\
\text { (Electoral Process and } \\
\text { Pluralism) }\end{array}$ \\
\hline No & Mean & 6.0991 & 6.7951 \\
& N & 116 & 116 \\
\multirow{2}{*}{ Yes } & Std. Deviation & 2.13017 & 3.34544 \\
& Mean & 4.0628 & 4.1021 \\
& N & 39 & 39 \\
Total & Std. Deviation & 1.50643 & 2.87212 \\
& Mean & 5.5868 & 6.1175 \\
& N & 155 & 155 \\
& Std. Deviation & 2.17585 & 3.43040 \\
\hline
\end{tabular}

The results in table show that the least developed countries have lower scores than the other countries both for the overall evaluation of democracy and for the evaluation of the electoral process and pluralism.

\section{CONCLUSION}

The results show that there is statistically significant relationship between the statute of least developed countries and their electoral system on one hand and their regime type on other. The LDCs are mostly with authoritarian political regimes and have majority/plurality systems. As mentioned above the latter can ensure natural or manufactured majority and the majority produces stability. Having in mind that most of these regimes are authoritarian or hybrid, we can conclude that there is high level of probability that in LDCs the majority/plurality system produces a "manufactured" majority. Thus, the government has power with little or no control by other political players.

There is also a statistically significant difference in the scores of least developed countries compared to all others regarding the evaluation of democracy and the electoral process and pluralism. This means that LDCs has lower quality of democracy and the same is valid for their electoral process and pluralism. So in these countries the electoral system, no matter of its type, doesn't produce the effect, relevant for a democratic country.

\section{ACKNOWLEDGMENTS}

This article is a part of a project № SP19FISN-006, financed by Fund "Scientific research" at the University of Plovdiv Paisii Hilendarski.

\section{REFERENCES}

1. Cortona, P.G.D., Manzi, C., Pennisi, A., Ricca, F., and Simeone, B., Evaluation and optimization of electoral systems. Society for Industrial and Applied Mathematics, Philadelphia, 1987;

2. Benoit, K., Duverger's Law and the Study of Electoral Systems. French Politics 4: 69-83, 2006;

3. Blais, A., Massicotte, L., 1996. Mixed electoral systems: An overview. Representation, 33: 115-118, 1996

4. Norris, P., Choosing Electoral Systems: Proportional, Majoritarian and Mixed Systems. International Political Science Review, 18: 297-312, 1997

5. Norris, P., Electoral engineering: voting rules and political behavior. Cambridge University Press, Cambridge, 2004

6. Ortona, G., Choosing the Electoral System: Why Not Simply the Best One? SSRN Electronic Journal, 2003

7. Curini, L. and Martelli, P., Electoral Systems and Government Stability: A Simulation of 2006 Italian Policy Space. AUCO Czech Economic Review, 3: 305322, 2009

8. European Commission for Democracy through Law (Venice Commission) Report on the impact of electoral systems on women's representation in politics, Strasbourg, 2009

9. Acemoglu, D. and Robinson, J.A., Economic origins of dictatorship and 
democracy. Cambridge University Press, New York, USA, 2012

10.www.un.org/development/desa/dpad/wpcontent/uploads/sites/45/Snapshots2018.pdf

11.https://aceproject.org/

12.https://data.ipu.org/

13.https://www.idea.int/data-tools/questionview/130357

14.https://www.ifes.org/
15.The Economist Intelligence Unit, Democracy Index 2018: Me too? Political participation, protest and democracy. The Economist Group, London, UK, 2019

16.16.

https://unctad.org/en/pages/aldc/Least $\% 20$

Developed\%20Countries/UN-list-of-Least-

Developed-Countries.aspx 